\title{
Expert Views on the Depth of Ecological Concepts at the Elementary and Middle School Levels
}

\author{
Susanti Wulandari ${ }^{1, *}$ Nuryani Yogipranata Rustaman ${ }^{2,}$ Ari Widodo ${ }^{2,}$ I Nyoman \\ Pugeg Aryantha ${ }^{3}$ \\ ${ }^{1}$ Master of Natural Science Education, Postgraduate School, Universitas Pendidikan Indonesia, Indonesia \\ ${ }^{2}$ Department of Natural Science Education, Postgraduate School, Universitas Pendidikan Indonesia, Indonesia \\ ${ }^{3}$ School of Life Sciences and Technology, Institut Teknologi Bandung, Indonesia \\ *Corresponding author. Email: susantiwulandari@upi.edu
}

\begin{abstract}
Continuing education is one of the main goals of success in the education sector. Quality human resources are the supporting aspect for the success of education. Teachers play an active role in preparing their students to live in the era of the society revolution 5.0. This study aims to investigate the depth of ecological content to be mastered by the teachers of elementary, junior, and senior high schools. Online interviews and questionnaires were conducted on 3 ecologists from three different universities. The results of the interviews were analyzed qualitatively using a grounded theory research design. The data was transcribed and sorted based on the appropriate conceptual themes between ecological opinions. Data analysis is carried out with applicable curriculum and other research results. A new theory is formed that emphasizes the suitability of ecological opinions and educational levels. Based on the analysis of in-depth interviews with ecologists, it is known that there are differences in the scope and depth of ecological content to be mastered by elementary, junior, and senior high school teachers. At the elementary level, teachers should master the concept of environment and survival. Junior high school teachers should master the concepts of healthy lifestyle and energy. Meanwhile, senior high school teachers, in addition to mastering the material taught to elementary and junior high school students, should master concepts related to science and technology and ecosystem services. It is expected that the results of this study be a reference for the adjustment and reorientation of biology material.
\end{abstract}

Keywords: Ecology, Content knowledge, Elementary school level, Middle school level

\section{INTRODUCTION}

Ecology is a branch of biology to be mastered by prospective teachers and teachers who will teach biology, as well as science teachers for junior high schools and elementary school teachers. This important biological science must be mastered by a bachelor of biology and biology education [1], [2]. The central role of subject matter is manifested as a component that becomes a reference in the process of constructing knowledge and is pivotal in the learning process [3]. The structure of the material describes a concept and the relationship between concepts, both vertically and horizontally, which describes the equivalence of levels [4].
Currently, students across the world are faced with various future challenges, indicated by the characteristics of volatility, uncertainty, complexity, and ambiguousness. Students as the next generation are required to get through these characteristics [5]. The revolution of industry 4.0 which is marked by integrated manufacturing, wireless technology and big data has also colored the education sector [6]. Likewise, the era of society 5.0 which was initiated by Japan is about technology as well as policies and regulations. Future technologies such as Artificial Intelligence (AI), robots, and drones put humans in control. Besides, big data is used to create a humanized smart society [7].

Current learning transformations in several countries affected by the Covid-19 pandemic, 
including in Indonesia include the use of technology and social media in distance learning and the transformation of learning designs and assessment models. The transformation aims to implement effective and efficient learning processes. Despite many obstacles faced by teachers, students, and even parents in using technology, learning, and financing [8], the learning process is still carried out, and teachers must have good and balanced Pedagogical Content Knowledge (PCK) skills. The results of research [9] indicate that the stability and level of PCK that teachers have influenced how they present integrated learning.

Referring to the National Science Teacher Association Standards for Science Teacher Preparation [10] regarding the content standards that must be possessed by science teachers, especially on biology materials, there are differences in the level of content knowledge to be mastered by science teachers at elementary, junior, and senior high school levels. This study aims to investigate the depth of ecological content to be mastered by the teachers of elementary, junior, and senior high schools. The results of this study can be a recommendation for education policymakers to reorient and reform ecology material in the education of pre-service teachers of elementary school, pre-service science teachers of junior high school, and pre-service biology teachers of senior high school biology in universities.

\section{RESEARCH METHOD}

Three ecologists from three different universities were involved in this study; they are ecologists from the State University of Malang, Bandung Institute of Technology, and the Indonesia University of Education. They were interviewed at different times with the same question of "How deep should the ecological content be mastered by elementary school teachers, junior high school science teachers, and senior high school biology teachers?". The researcher had asked their permission for interviews; then, the researcher sent several questions via online media so that the three experts would answer them and asked for time to fill out the questionnaire or questions given.

The data collection process lasted for 6 months from May to October 2020. Interview data in the form of online conversations on social media with the experts were transcribed and coded. In the data analysis process, the researcher read the entire text of the interview results with each ecologist carefully, followed by layering into concept themes and summarizing the views of the three experts in the table [11].

\section{RESULT AND DISCUSSION}

Based on the results of interviews with three ecologists, they have different views on the depth of ecological content to be mastered by the teachers and then taught to their students. According to their views, the ecology material given to elementary, junior, and senior high school students places more emphasis on the application of the aggregate curriculum. In this case, the material provided to the students differs in types and depth of content (vertical dimension). The following is an illustration of the researcher's interview with an ecologist.

Researcher: "In your opinion, what concepts should be mastered by a teacher regarding ecology material at the elementary, junior, and senior high school levels?"

Ecologist: Spiral approach (teaching the same content more deeply or broadly in the three levels of school) or aggregate approach (different sets of content with different depth and breadth in the three levels of school). Again, this depends on the goals and curriculum design set. The concept map in the vocational school curriculum, for example, will include more applications and techniques rather than the theory and concepts of a selected science branch, while, in the academic school or public school curriculum, more general knowledge and concepts are preferred. Regarding the depth of content, of course, it differs between theoretical, conceptual, application, and technical contents. Ecology covers a wide field from population to biosphere with more than 50 major theories and concepts. Choose the type of content that is suitable and required for each curriculum. It is not necessary to teach ecology as in the university textbook. Determine the depth according to the functions listed in the curriculum. However, this depth of material in elementary, junior, and senior high schools cannot be separated from the development of Bloom's realm. This is different from university students who are adults so that they can use teaching materials maximally.

Thus, the depth of content for the three levels of school depends on the function of the content in the curriculum (learning). It also depends on the level of cognitive, psychomotor, and attitudes among the students. For example, in the spiral approach curriculum in elementary school, succession theory in ecology is taught at the level of how students can plant various types of trees in the same type of soil 
with organic fertilizers and natural pesticides which are related to cognition, psychomotor, and attitudes of children under 12 years old. When they have been in junior high school, succession theory is taught again with the target of how students can design an agroforestry land in a dry land using hand tractors, chemical fertilizers, and pesticides. In senior high school, this theory is taught again by adding the calculation of capital and profit analysis as well as production and demand forecasting. This kind of learning will be useless if the students go to school in a city with no extensive agricultural land to be cultivated as they graduate (irrelevant content and depth). Table 1 is a summary of the results of interviews with the three ecologists.

Table 1. Summary of the results of interview with ecologists

\begin{tabular}{|c|c|c|c|}
\hline \multirow[t]{2}{*}{ Questions } & \multicolumn{3}{|c|}{ Level } \\
\hline & Elementary School & Junior High School & Senior High School \\
\hline $\begin{array}{l}\text { What ecological concepts } \\
\text { should be mastered by } \\
\text { teachers? }\end{array}$ & $\begin{array}{l}\text { The concept of environment } \\
\text { and survival }\end{array}$ & $\begin{array}{l}\text { Concepts related to healthy } \\
\text { living and energy }\end{array}$ & $\begin{array}{l}\text { Concepts related to } \\
\text { science and technology } \\
\text { (Sci-Tech) and ecosystem } \\
\text { services }\end{array}$ \\
\hline $\begin{array}{l}\text { To what extent should } \\
\text { ecological concepts be } \\
\text { mastered by teachers? }\end{array}$ & $\begin{array}{l}\text { a. Biotic and abiotic factors } \\
\text { b. Trophic level } \\
\text { c. Food chain } \\
\text { d. Water cycle } \\
\text { e. The role of the } \\
\text { environment for humans } \\
\text { f. How humans should } \\
\text { treat the environment } \\
\text { g. Environmental } \\
\text { properties }\end{array}$ & $\begin{array}{l}\text { a. Energy flow } \\
\text { b. Cycle of matter } \\
\text { c. Population size } \\
\text { d. Carrying capacity } \\
\text { e. Crowded effect } \\
\text { f. Carrying capacity of } \\
\text { ecosystem components } \\
\text { g. Pollution } \\
\text { h. Interaction of living things } \\
\text { with the environment }\end{array}$ & $\begin{array}{ll}\text { a. } & \text { Biodiversity } \\
\text { b. } & \text { Bioconservation } \\
\text { c. } & \text { Ecosystem services } \\
\text { d. } & \text { Climate change } \\
\text { e. } & \text { Global warming } \\
\text { f. } & \text { Pollution } \\
\text { g. } & \text { Ecological basics } \\
\text { h. } & \text { Relationship between } \\
& \text { biodiversity and } \\
& \text { ecology } \\
\text { i. } & \text { Interaction of humans } \\
& \text { with the environment }\end{array}$ \\
\hline
\end{tabular}

\subsection{The Depth of Ecological Content to Be Mastered by Elementary School Teachers}

Based on the results of the analysis of interviews with ecologists, the ecological content to be mastered by elementary school teachers is related to the concept of environment and survival. The concept consists of:

a. Introduction of environmental components consisting of biotic and abiotic factors.

b. Food chain which describes the relationship between producers, primary consumers, secondary consumers, and decomposers.

c. Trophic levels occupied by living things in the environment.

d. Water cycle.

e. The role of the environment for humans (the concept of environmental carrying capacity).

f. Environmental properties.

g. How humans should treat the environment.

This expert thinking is based on multi-level curriculum design, namely that the curriculum is prepared to provide useful knowledge for students' lives. In other words, students benefit from the ecological concept after they learn about this concept. If they cannot continue their studies at the junior high school level, they can use the knowledge about the concept of the environment and survival they get from the elementary school level in their lives. Thus, pre-service and in-service teachers at elementary school should master the ecological material that emphasizes more on the function of the concept taught rather than the complexity of the material.

Elementary school teachers should carry out a lot of hands-on activities to introduce the real environment to students in a more fun way. Project Learning Tree recommends elementary school teachers to ask their students to make direct observations outside the classroom, write down the living things they find, and find the relationships among these living things. These activities can provide direct experience to students about ecosystems, and they can build their understanding of the concept of ecosystems. Teachers are highly required to provide stimulation in the form of prompting questions to guide their students to observe the environment, how living things get food so that they find their understanding of the connectedness of every living thing in an environment [12]. 


\subsection{The Depth of Ecological Content to Be Mastered by Junior High School Teachers}

Based on the opinion of ecologists regarding the content to be mastered by science teachers at junior high school, it is known that they should master concepts related to healthy living and energy. The detailed concepts to be mastered by science teachers at junior high school are described in Table 1.

Teachers must be able to distinguish between the concepts of energy flow and the cycle of matter. It is called energy flow because the energy obtained by an organism will decrease along with the food chain. Teachers can teach energy flow material easily by explaining about the food chain and trophic levels. However, according to the ecologists, what students should know first is the concept of the food chain and trophic levels at the elementary school level. Only then can they be asked to think about energy flow after having a correct understanding of trophic levels and food chain. Teachers should have the ability to sort and determine the order of the important concepts given first, which is one of the pedagogical abilities. Therefore, when talking about content and which levels of students are taught, content cannot be separated from pedagogy because PCK is an absolute ability that must be possessed by a teacher, as emphasized by [13]. Teachers should master content and know the appropriate and relevant methods in teaching.

Another ecological concept that seems to have been given by the elementary school teachers to their students is the concept of the interaction of living things in the environment, for example, the concept of mutualism, which is an interaction that benefits living things. A bee sucking nectar, or a flower get their food from the sugar in the flower while the flower has been indirectly assisted by the bee in the pollination process. If students can observe directly and the teacher explains this interaction responsively, students will understand the meaning of mutualism and can use it for the interactions of other living things.

Another important concept for junior high school teachers is the concept of pollution. Teachers need to understand the meaning of pollution, its types, causes, and impacts for humans and other living things, as well as pollution prevention efforts that can be carried out by humans. The national curriculum (both school-based curriculum or KTSP and the revised 2013 curriculum) and the international curriculum, for example, the Cambridge curriculum, has a different emphasis. In the national curriculum textbook, students are more directed to understand pollution in terms of content (definition, types, impacts, causes, and prevention efforts). Meanwhile, in the Cambridge curriculum, the material on environmental pollution emphasizes the environmental context such as air pollution, habitat destruction, water pollution, and species decline, for example, the main causes and possible solutions [14].

\subsection{The Depth of Ecological Content to Be Mastered by Senior High School Teachers}

Table 1 shows that biology teachers at senior high school must master the concepts related to science and technology and ecosystem services. Biodiversity in the revised 2013 curriculum that applies in Indonesia is contained in the biology material for the tenth grade. In the discussion about biodiversity, teachers must master the contents about the meaning of biodiversity, the level of biodiversity (genes, species, and ecosystem), the biodiversity of Indonesian plants and animals, and efforts to maintain and preserve biodiversity. The applicable national curriculum does not specifically discuss bioconservation, but, in the Cambridge curriculum conservation, there is a special discussion which includes the efforts to maintain the biodiversity of species and their habitats, recycling of waste to reduce the use of excess water from the environment, and paper recycling to conserve plants as raw material for paper. In schools that use the Cambridge curriculum, Science, Technology, Engineering, and Mathematics (STEM)-based learning has been widely applied in science learning about ecology, especially in activities that can facilitate students to recycle wastewater and paper directly through the activities of Design-Thinking, Test, and Redesign [15], [16]. Conservation activities through STEM-based learning can facilitate students to have interdisciplinary thinking skills and practice argumentative skills [15]. These activities provide much real experience that can train students to have engineering skills and find solutions through various ideas and experiments [16].

Environmental issues at local, national, and global scales that are important for teachers to master in supporting ecology learning are, such as, climate change and global warming. In the issue of climate change, teachers must understand the causes of climate change in the world, the impact on humans and living things, and how humans can survive the climate change situation. For the issue of global warming, senior high school teachers must understand the concept of the greenhouse effect, 
causes of global warming, and how to reduce the rate of global warming.

It seems that there is a repetition of material about pollution and the interaction of living things in the environment. Both materials have been suggested to be taught at the junior high school level, but preservice and in-service teachers at senior high schools should have a deeper understanding of and develop pollution and interaction material. The following is an illustration of the researcher's interview with an ecologist.

Researcher: "In your opinion, to what extent should the ecology material be mastered by a biology teacher at senior high school?"

Ecologist C: The ecological concepts that should be mastered by senior high school teachers are regarding pollution, the basics of ecology, the relationship between biodiversity and ecology, and the interaction of the environment with humans. To what extent? I think it is the same as for junior high school teachers. In my opinion, if the teacher has mastered the basic ecological concepts as the requirements for passing ecology courses and other courses such as ecophysiology, plant and animal ecology is the minimum depth of material to be mastered if they want to senior high school teachers.

This statement indicates the importance of preservice or in-service teachers to have a good provision and learning experience during their education at university. Biology teachers need to understand ecology material contained in several subjects such as ecophysiology, general ecology, plant ecology, and ecology. [17] recommend that the education of pre-service teachers, not separate schools and campuses because teachers and students in schools can provide feedback on the teaching process carried out by the pre-service teacher. This is as stated by [18] that it is important to innovate through various systematic and planned efforts to improve the PCK of in-service or pre-service teachers in teacher education on campus. The study by [19] on the PCK profile of pre-service science teachers shows that pre-service science teachers with high teaching practice scores can make more detailed lesson plans compared to those with moderate and low scores. This indicates that a teacher who has good teaching skills has good content knowledge and pedagogy [9].

The rapid growth and development of the human community have made ecological literacy a part of lifelong learning experiences, starting from elementary school to the level of informal adult learning experiences. The goal of the Ecological
Society of America's (ESA) on education is to improve ecological education at all ages and for the public [20].

The ecological literacy framework considers a broad knowledge sphere which ideally includes (1) scientific habits of mind with respect to ecology (e.g., a set of reasoning), (2) ecological connectivity and key concepts (e.g., island biogeography theory), and (3) self-knowledge with respect to human action and environmental linkages (e.g., different levels of abstraction). These spheres are overlapping at various levels, depending on the individual, but there are areas of ways of knowing mediated by ecological literacy [20].

Certain habits of mind such as modeling, understanding environmental uncertainty, and scale issues are integral to scientific inquiry and lead to the ecological context in learning [20]. Elementary and high school students often have difficulty understanding issues of scale and uncertainty when using and interpreting a model [21].

ESA forum [20] describes eight fundamental ideas regarding biotic and abiotic factors that influence the distribution of species to be mastered by teachers; they are organisms (individual, population, and ecophysiology), the concept of species, evolutionary processes (natural selection, macroevolution, and gene change), regional and global issues, population dynamics (exponential growth, logistical growth, and mathematical models), population interactions, biodiversity, food webs, trophic levels, energy flow, productivity, biogeochemical cycles, and allocation/trade-offs.

\section{CONCLUSION}

According to experts, the depth of ecological content that elementary, junior, and senior high school teachers should master varies. Elementary school teachers should master the concept of environment and survival. Junior high school teachers should master elementary school material and concepts related to healthy living and energy. Meanwhile, senior high school teachers must have more in-depth and integrated content mastery related to science and technology and ecosystem services. Although the depth of content at each level is different, as professional teachers, especially science and biology teachers, they should master the eight fundamental ideas related to biotic and abiotic factors as recommended by ESA. The concepts relating to the ESA formulation and the opinion of ecologists are the concepts of organisms, population dynamics, 
population interactions, biodiversity, food webs, trophic levels, energy flow, and biogeochemical cycles.

\section{ACKNOWLEDGMENTS}

We thank those who helped the researcher, especially thanks to Dr. Vivi Novianti, M.Si from Universitas Negeri Malang, Dr. Achmad Sjarmidi from Institut Teknologi Bandung and Dr. Wahyu Surakusumah, S.Si., M.T. from Universitas Pendidikan

Indonesia who have been participated in this research as the ecologists.

\section{REFERENCES}

[1] Konsorsium Biologi Indonesia KOBI, Rumusan Naskah Akademik Standar Nasional Berbasis KKNI, KOBI, 2015.

[2] Konsorsium Biologi Indonesia KOBI, Rumusan Naskah Akademik Standar Nasional Berbasis KKNI, KOBI, 2017.

[3] R. Duit, D.F. Treagust, A. Widodo, Teaching Science for Conceptual Change: Theory and Practice, International Handbook Research Conceptual Change (2008) 629-646.

[4] R.W. Dahar, The Theories Learning, Erlangga, 1996.

[5] K.K Patel, S.M. Patel, Internet of Things-IoT: Definition, Characteristics Architecture, Enabling Technologies, Application and Future Challenges, International. Journal of Engineering, Science and Computer 6(5) (2016) 6122-6231.

[6] R. Morrar, H. Arman, S. Mousa, The Fourth Industrial Revolution (Industry 4.0): A Social Innovation Perspective Technology Innovation Management. Review 7(11) (2017) 12-20.

[7] M. Fukuyama M, Society 5.0: Aiming for A New Human-centered Society, Special Article Japan Spotlight (2018) 47-50.

[8] A. Hatip, The transformation of learning during covid-19 pandemic towards the new normal era, in: Proceding International Webinar on Education,Universitas Muhamadiyah Surabaya, Surabaya, 2020, pp. 18-28.

[9] M.J.A Putra, A. Widodo, W. Sopandi, 2017, Science teachers' pedagogical content knowledge and integrated approach, in Journal of Physics: Conference Series, vol. 895, IOP Publishing, Bristol, 2017, pp. 1-5, DOI: https://doi.org/10.1088/17426596/895/1/012144.
[10] National Science Teacher Association, Standard for science teacher preparation, NSTA, Feb. 2003. Accessed on Feb. 2, 2021, [Online]. Available: http://www.nsta.org

[11] J.W. Creswell, Educational Research: Planning, Conducting, and Evaluating Quantitative and Qualitative Research (Fourth Edition), Pearson, 2007.

[12] Project Learning Tree, Hands-on Activities for Introducing Ecosystem to Elementary Students, Sustainable Forestry Initiative, 2019.

[13] L. Shulman, Knowledge and Teaching: Foundations of The New Reform, Harvard Eduational Review 57(1) (1987) 1-23.

[14] M. Jones, G. Jones, IGCSE Biology Coursebook: Second Edition, Cambridge CB2: Cambridge University Press, 2010.

[15] S. Wulandari, N.Y. Rustaman, A. Rahmat, Interdisciplinary Thinking Skill of Upper Secondary Students In STEM-Based Instruction On Plant Reproduction, Universitas Pendidikan Indonesia, 2017.

[16] B.K. Sejati, Developing Science-TechnologyEngineering-Mathematics (STEM)-based Workbook to Enhance Secondary Students' STEM Competencies on Level System in Human Body, Universitas Pendidikan Indonesia, 2016.

[17] Y. Anwar, N.Y. Rustaman, A. Widodo, Hypothetical Model to Developing Pedagogical Content knowledge (PCK) Prospective Biology Teachers in Consecutive Approach, International Journal of Science and Research, 12(3) (2014) 138-143. DOI:

[18] A. Widodo, Experienced biology teachers' pedagogical content knowledge (PCK) on photosynthesis, in: AIP Conference Proceeding, AIP Publishing, College Park, Maryland, 2017.

[19] J.M. Aguirre, S.M. Haggerty, C.J. Linder, Student-teachers' Conceptions of Science, Teaching and Learning: A Case Study in Preservice Science Education, International Journal of Science Education 12(4) (1990) 381390 , DOI: https://doi.org/10.1080/0950069900120405

[20] R. Jordan, F. Singer, J. Vaughan, A. Berkowitz, What should every citizen know about ecology?, Frontiers in Ecology and the Environtment 7(9) (2008) 495-500.

[21] D.F. Treagust, G. Chittleborough, T.L. Mamiala, Students' Understanding of The Role of Scientific Models in Learning Science, International Journal of Science Education 24(4) (2002) 357-368

DOI: https://doi.org/10.1080/09500690110066485 